\title{
Media Pembelajaran Menggunakan Video Atraktif pada Materi Garis Singgung Lingkaran
}

\author{
Livia Agna Putri ${ }^{1 *}$, Putri Sukma Dewi \\ ${ }^{1,2}$ Universitas Teknokrat Indonesia \\ ${ }^{*}$ liviaagna@gmail.com
}

\begin{abstract}
Abstrak
Tujuan penelitian ini adalah membantu siswa dalam proses belajar materi garis singgung lingkaran melalui video atraktif. Di era sekarang, teknologi baru yang terus berkembang tentunya dapat mempermudah seseorang dalam mendapatkan informasi. Anshor mengemukakan bahwa kemajuan teknologi di era sekarang dapat membawa pengaruh besar di bidang pendidikan bagi guru maupun siswa. Penulis melakukan penelitian pengembangan media pembelajaran pada materi lingkaran subbab garis singgung lingkaran yang diharapkan dapat membantu siswa dalam proses belajar. Penelitian ini menggunakan metode Research and Development $(R \& D)$. Penulis melakukan pengembangan media pembelajaran menggunakan Microsoft PowerPoint untuk desain slide, animasi, dan transisi yang kemudian dijadikan sebuah video serta Windows Movie Maker version 12 untuk pemasukkan suara. Hasil penelitian ini adalah sebuah produk berupa video pembelajaran tentang konsep garis singgung lingkaran menggunakan Micosoft PowerPoint dan Windows Movie Maker version 12 yang telah diuji pada 5 siswa SMP kelas VIII. Berdasarkan pernyataan kelima siswa tersebut, materi yang disampaikan dalam video dapat dipahami dan membuat siswa tertarik dengan video pembelajaran.
\end{abstract}

Kata Kunci: media pembelajaran, video atraktif, garis singgung.

\begin{abstract}
The purpose of this study is to help students in the process of learning tangent circles through attractive videos. In the current era, new technology that continues to develop makes it easier for someone to get information. Anshor argued about technological advancements in the present age which can bring a great influence in the field of education for teachers or students. The author conducts research into the development of instructional media in the material circle circle tangent circle which is expected to help students in the learning process. This research uses the Research and Development (R\&D) method. The author makes the development of learning media using Microsoft PowerPoint to design slides, animations, and transitions which are then made videos and Windows Movie Maker version 12 for sound input. The results of this study are a product consisting of a learning video about the concept of tangent circles using Microsoft PowerPoint and Windows Movie Maker version 12 which has been supported by 5 grade VIII students. Based on the student's agreement, the material presented in the video can be understood and makes students interested in video learning.
\end{abstract}

Keyword: learning media, attractive video, tangent circle.

\section{Pendahuluan}

Garis singgung lingkaran merupakan salah satu subbab materi yang diajarkan di kelas VIII Sekolah Menengah Pertama (SMP). Menurut Sowanto (2018), salah satu konsep matematika yang dipelajari mulai dari sekolah dasar sampai menengah atas, bahkan sampai di perguruan tinggi pun dipelajari secara lebih mendalam bagi mahasiswa yan mengambil bidang keahlian matematika, serta dipelajari secara terintegrasi dan kontinu 
adalah konsep lingkaran. Konsep lingkaran adalah konsep dasar yang harus dipahami lebih lanjut untuk memahami mengenai konsep bangun ruang sisi lengkung (Rikanah: 2016).

Namun, masih banyak siswa yang mengalami kesulitan dalam memahami konsep lingkaran. Yunus, Suyitno, dan Wahyudin (2013) juga mengungkapkan bahwa siswa seringkali mengalami kesulitan dalam mempelajari materi geometri terlebih khusus garis singgung lingkaran. Menurut Soejono (1984:4) terdapat 3 kesulitan khusus dalam belajar matematika yaitu: 1) kesulitan dalam menggunakan konsep; 2) kesulitan dalam belajar dan menggunakan prinsip; 3) kesulitan memecahkan soal berbentuk verbal. Dengan kata lain, siswa mengalami kesusahan pada aspek pemahaman dan aspek perhitungan. Sholikhah, Budiyono, dan Saputro (2014) menduga salah satu faktor kesulitan siswa dalam menguasai materi adalah cara guru dalam menyampaikan materi ajar.

Seiring perkembangan zaman, seseorang dapat memperoleh informasi secara mudah melalui teknologi baru yang terus berkembang. Perkembangan teknologi ini dapat menjadi menguntungkan di bidang pendidikan bagi guru maupun siswa. Untuk itu diperlukan strategi yang tepat untuk mencapai hasil belajar yang optimal. Guru harus dapat meningkatkan strategi belajar dengan pemilihan sarana pembelajaran yang tepat. Hasil belajar siswa dipengaruhi oleh berbagai faktor, seperti motivasi belajar, metode pengajaran, sarana dan prasarana yang berupa media pembelajaran (Anshor: 2015). Menurut apa yang dinyatakan Turmudi (2009), pembelajaran matematika merupakan salah satu bidang ilmu yang selalu berkaitan dengan adanya guru, siswa, dan materi sebagai salah satu sumber bahan ajar.

Media pembelajaran merupakan salah satu komponen yang mempunyai peranan penting dalam pembelajaran (Anshor: 2015). Media pembelajaran, seperti video pembelajaran yang menggunakan audio dan visual, dapat membuat pelajaran menarik dan tidak monoton sehingga siswa akan merasa atraktif dengan belajar. Penulis berasumsi bahwa salah satu cara meningkatkan ketertarikan siswa pada materi garis singgung lingkaran yaitu dengan menggunakan media pembelajaran. Video pembelajaran dapat menjadi sarana belajar yang efektif bagi siswa. Pembelajaran yang berkualitas akan memperoleh hasil belajar siswa yang maksimal. Melalui menonton video yang sesuai dengan pembelajaran, siswa dapat memperluas kemampuan visualisasi siswa (Nies, M. L \&Walker, J. M: 2010). Tidak hanya visualisasi, siswa juga dapat mengasah kemampuan mendengar dan mendapatkan informasi melalui video. 
Menurut Theo Riyanto (2003), pembelajaran yang atraktif adalah suatu proses pembelajaran yang mempesona, menarik, mengasyikkan, menyenangkan, tidak membosankan, variatif, kreatif, dan indah. Tidak hanya menggunakan video pembelajaran dalam proses mengajar, tetapi pembelajaran yang efektif juga dapat meningkatkan minat belajar. Melalui pembelajaran yang atraktif, siswa dapat merasa menyenangkan saat proses belajar-mengajar.

Berdasarkan uraian diatas, peneliti ingin melakukan pengembangan media pembelajaran menggunakan video pembelajaran mengenai konsep garis singgung lingkaran pada materi pelajaran kelas VIII SMP. Dengan pembelajaran yang efektif juga diharapkan dapat membantu siswa dalam memahami konsep materi dan meningkatkan hasil belajar yang efektif.

\section{Metode Penelitian}

Penelitian ini menggunakan metode Research and Development $(R \& D)$. Produk yang diharapkan dari penelitian ini adalah video pembelajaran pada materi lingkaran subbab garis singgung lingkaran yang didesain menggunakan aplikasi PowerPoint dan diedit menggunakan aplikasi Windows Movie Maker version 12.

Alur pembuatan video pembelajaran dengan metode Research and Development $(R \& D)$ menggunakan desain Plomp dalam Ahmar dan Rahman (2017) sebagai berikut:

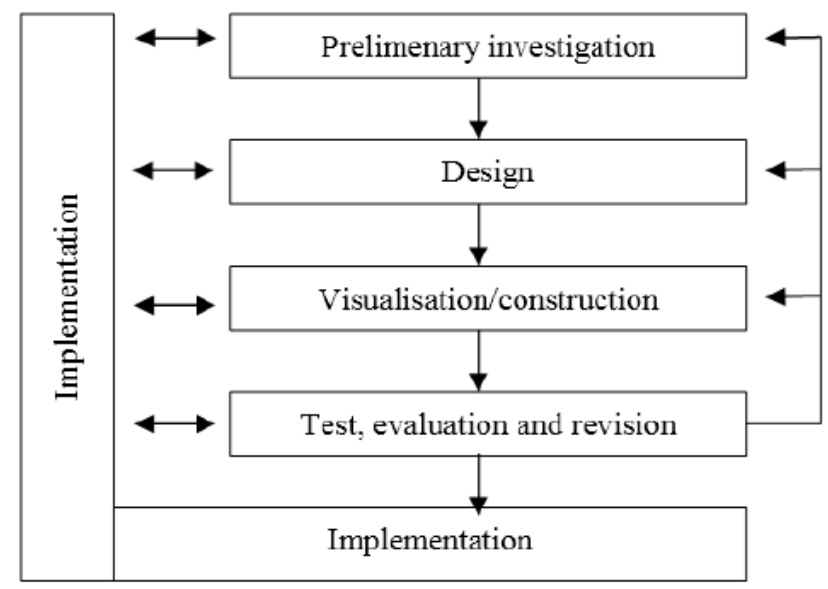

Gambar 1. Tahapan penelitian R\&D model Plomp.

Berikut penjelasan dari tahapan penelitian R\&D menggunakan desain Plomp:

\section{Studi Kasus dan Pengumpulan Data (Prelimenary Investigation)}

Penulis mengumpulkan data yang diperlukan untuk pengembangan aplikasi dengan mewawancarai siswa kelas VII yang bertempat tinggal di Jagabaya I tentang apa saja masalah yang dihadapi saat belajar matematika terutama pada materi lingkaran subbab 
garis singgung lingkaran. Selain itu, penulis juga melakukan studi pustaka terkait data dan masalah.

\section{Desain Produk (Design)}

Desain produk ini merupakan isi atau komponen-komponen yang ada dalam video pembelajaran dan dibuat semenarik mungkin agar siswa tertarik untuk belajar. Isi desain produk adalah sebagai berikut:

a. Judul materi;

b. Konsep awal materi;

c. Pengertian materi;

d. Merumuskan rumus pada materi; dan

e. Contoh masalah dan penyelesaiannya.

\section{Pembuatan Produk dan Visualisasi (Construction and Visualisation)}

Pada tahap ini, terdapat beberapa tahap yang dilakukan dalam pembuatan produk dan visualisasi yaitu sebagai berikut:

a. Penggunaan Tampilan dan Animasi

Pada tahap ini, produk dirancang menggunakan Microsoft PowerPoint dengan mengandalkan fitur-fitur seperti animasi, transisi, latar belakang, dll. Penggunaan tampilan dan animasi bertujuan untuk memudahkan siswa dalam belajar secara beurutan dan membuat siswa tertarik pada video pembelajaran. Setelah desain produk dengan Microsoft PowerPoint selesai, maka file tersebut akan diekspor menjadi sebuah video.

b. Penggunaan Suara

Tidak hanya mementingkan tampilan dan animasi, penulis juga menginput suara kedalam video yang sudah dirancang. Pada bagian ini, penulis menginput suara dengan aplikasi Windows Movie Maker Version 12.

\section{Pengujian dan validasi produk}

Setelah dilakukan perancangan dan pembuatan produk dengan aplikasi Microsoft PowerPoint dan Windows Movie Maker Version 12, dilakukan pengujian pada beberapa ahli untuk memastikan konten dalam video pembelajaran tersebut sesuai denggan kompetensi dasar yang ada dalam subbab materi dan kelayakan video untuk siswa. Selain validasi produk, penulis melakukan uji coba produk pada siswa kelas VIII SMP yang bertempat tinggal di Jagabaya 1 sebanyak 5 siswa dengan mengobservasi langsung dan mewawancarai siswa tersebut. 


\section{Implementasi dan Penafsiran Hasil}

Setelah dilakukan uji coba produk, penulis melakukan penafsiran hasil dengan menganalisa secara sederhana menggunakan hasil wawancara dan observasi langsung pada 5 siswa SMP kelas VIII di Jagabaya 1.

\section{Hasil dan Pembahasan}

Penelitian ini adalah penelitian dengan metode Research and Development $(R \& D)$ yang diharapkan membuat tertarik siswa dalam belajar matematika pada materi lingkaran. Hasil penelitian ini berupa video pembelajaran dengan materi lingkaran subbab garis singgung lingkaran. Hal yang penting dalam pembuatan media pembelajaran menggunakan video yaitu konten yang sesuai dengan kompetensi dasar yang harus dicapai siswa. Perancangan alur konten dapat dilihat pada Gambar 2.
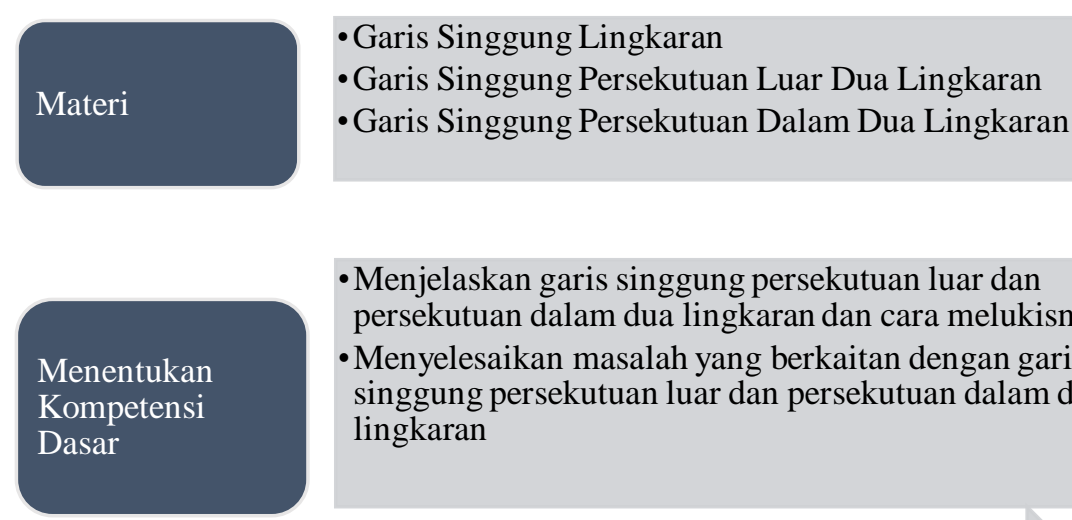

$$
\begin{aligned}
& \text { - Menjelaskan garis singgung persekutuan luar dan } \\
& \text { persekutuan dalam dua lingkaran dan cara melukisnya } \\
& \text { - Menyelesaikan masalah yang berkaitan dengan garis } \\
& \text { singgung persekutuan luar dan persekutuan dalam dua } \\
& \text { lingkaran }
\end{aligned}
$$

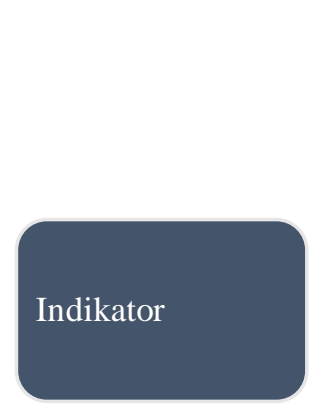

\footnotetext{
- Mengidentifikasi konsep garis singgung lingkaran

- Menemukan rumus jarak garis singgung lingkaran - Menyelesaikan masalah yang berkaitan dengan garis singgung lingkaran

- Menurunkan rumus untuk menentukan garis singgung persekutuan dalam dua lingkaran

- Menyelesaikan masalah yang berkaitan dengan garis singgung persekutuan dalam dua lingkaran

- Menurunkan rumus untuk menentukan garis singgung persekutuan luar dua lingkaran

- Menyelesaikan masalah yang berkaitan dengan garis singgung persekutuan dalam dua lingkaran
}

Gambar 2. Rancangan isi konten dalam video.

Pembuatan video menggunakan Microsoft PowerPoint untuk pengisian materi, animasi, transisi. Kemudian diekspor menjadi sebuah video dan diisi suara dengan aplikasi Windows Movie Maker version 12. Video yang telah selesai dilakukan uji validasi pada 
dua dosen pendidikan Matematika Universitas Teknokrat Indonesia. Hasil validasi yang divalidasi oleh ahli pendidikan matematika dapat dilihat pada Tabel 1.

Tabel 1. Hasil validasi ahli pendidikan matematika.

\begin{tabular}{|l|l|}
\hline \multicolumn{1}{|c|}{ Validator 1 } & \multicolumn{1}{c|}{ Validator 2 } \\
\hline Menambahkan sumber video & Merevisi indikator yang kurang sesuai \\
\hline $\begin{array}{l}\text { Merevisi materi pada konsep garis singgung } \\
\text { lingkaran }\end{array}$ & $\begin{array}{l}\text { Menambahkan video melukis garis } \\
\text { singgung }\end{array}$ \\
\hline Memperlambat transisi pada contoh soal & Merevisi suara \\
\hline
\end{tabular}

Setelah dilakukan validasi, maka diperlukan beberapa revisi sebelum produk diuji cobakan kepada siswa. Tampilan cuplikan pada video pembelajaran materi lingkaran subbab garis singgung lingkaran dapat dilihat pada Gambar 3.
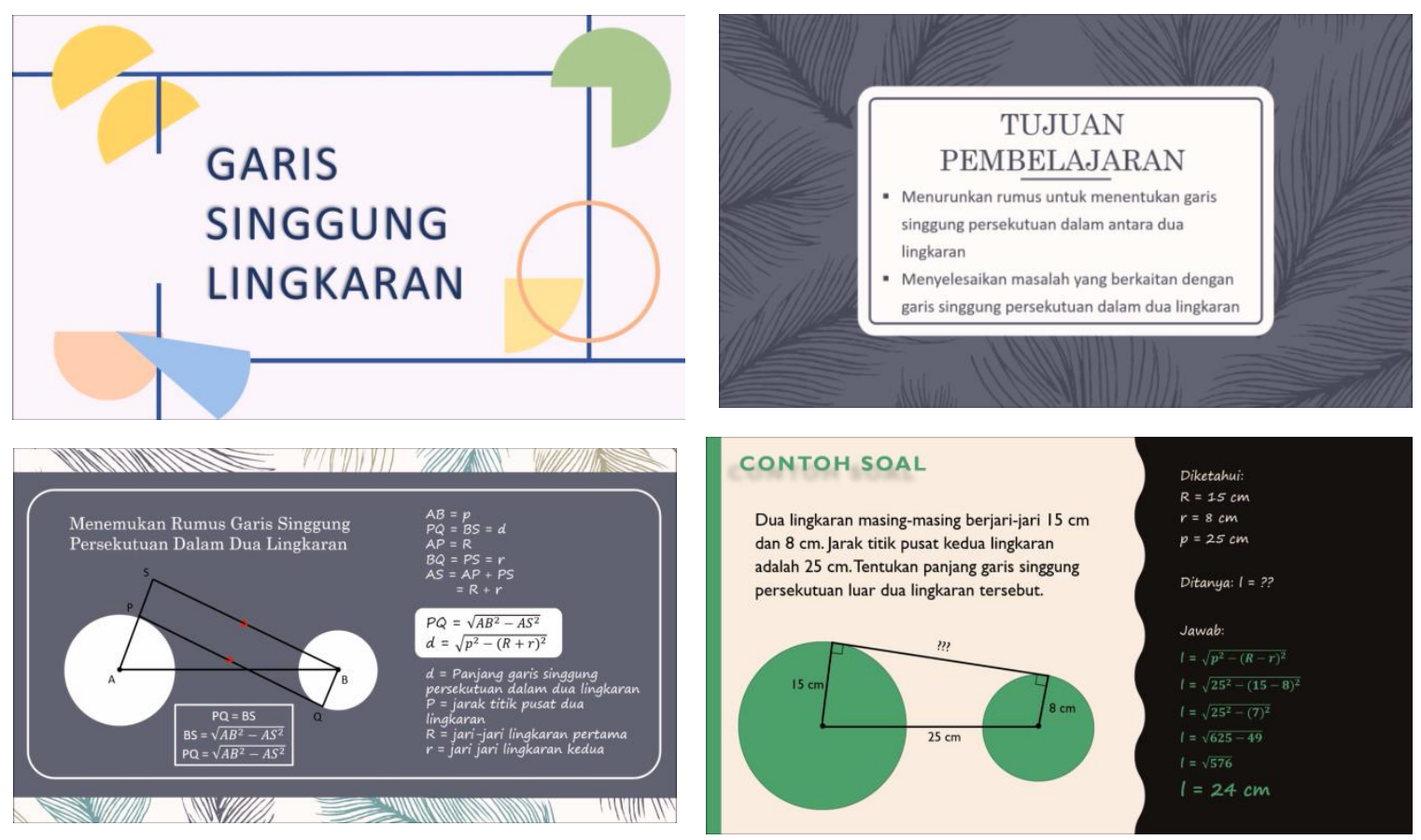

Gambar 3. Tampilan cuplikan video.

Penelitian ini berakhir pada tahap uji coba produk kepada 5 siswa SMP kelas VIII yang bertempat tinggal di Jagabaya I. Selanjutnya, penulis melakukan wawancara terhadap lima siswa tersebut mengenai pendapat mereka terhadap video pembelajaran tersebut. Deskripsi hasil penelitian secara rinci dapat dilihat pada Tabel 2. 
Tabel 2. Deskripsi Hasil Wawancara

\begin{tabular}{|c|l|}
\hline Siswa & Deskripsi \\
\hline Siswa 1 & $\begin{array}{l}\text { Ia berpendapat bahwa ia menyukai video pembelajarannya. } \\
\text { Menurutnya, belajar sambil menonton membuat materi lebih } \\
\text { mudah dipahami. }\end{array}$ \\
\hline Siswa 2 & $\begin{array}{l}\text { Ia mengatakan ia dan teman-temannya dapat lebih } \\
\text { memahami materi karena video ini dapat dilihat berkali-kali } \\
\text { juga lebih praktis. }\end{array}$ \\
\hline Siswa 3 & $\begin{array}{l}\text { Ia mengaku bahwa ia menyukai isi materinya karena dibuat } \\
\text { lebih mudah dan mengasyikkan. }\end{array}$ \\
\hline Siswa 4 & $\begin{array}{l}\text { Ia merasa senang belajar materi menggunakan video dan } \\
\text { merasa paham dengan materinya. }\end{array}$ \\
\hline Siswa 5 & $\begin{array}{l}\text { Ia mengaku materi yang ada di video mudah dipahami } \\
\text { sehingga ia merasa tertarik untuk terus belajar menggunakan } \\
\text { video. }\end{array}$ \\
\hline
\end{tabular}

Berdasarkan pernyataan kelima siswa tersebut, bahan ajar menggunakan video dapat dijadikan salah satu alternatif dalam pembelajaran matematika pada materi garis singgung lingkaran. Kelima siswa tersebut juga dapat memahami materi yang terdapat dalam video dan merasa tertarik belajar menggunakan video.

\section{Simpulan dan Saran}

Hasil penelitian ini adalah sebuah produk berupa video yang dapat digunakan siswa untuk belajar materi lingkaran subbab garis singgung lingkaran. Video pembelajaran dapat bermanfaat dan berdampak baik pada proses pembelajaran siswa. Penulis mengharapkan adanya penelitian lanjutan untuk membuktikan apakah media pembelajaran yang telah dibuat dapat diimplementasikan pada siswa SMP kelas VIII.

\section{Referensi}

Ahmar, A. S. \& Rahman, A. 2017. Development of Teaching Material using an Android. Global Journal of Engineering Education, 19(1):72-76

Anshor, Sokhibul. 2015. Penggunaan Media Pembelajaran Berbasis Video Terhadap Aktivitas Dan Hasil Belajar Geografi.

Niess, M. L. \& Walker, J. M. 2010. Guest editorial: Digital videos as tools for learning mathematics. Contemporary Issues in Technology and Teacher Education, 10(1), 100-105.

Rikanah, Dewi dan Winarso, Widodo. 2016. Penguasaan Konsep Lingkaran Terhadap Kemampuan Spasial Matematika Siswa Pokok Bahasan Bangun Ruang Sisi Lengkung Kelas VIII SMP Negeri 1 Kota Cirebon. Jurnal Pendidikan Matematika, Volume 10, Nomor 1, Januari 2016. 
Riyanto, Theo . 2003. Pendidikan dan Pembelajaran Atraktif. Artikel tidak diterbitkan.

Sholikhah, O. H., Budiyono, \& Saputro, D. R. S. 2014. Eksperimentasi Model Pembelajaran Kooperatif Tipe Group Investigation (GI) dan Numbered Heads Together (NHT) pada Materi Garis Singgung Lingkaran Ditinjau dari Kecerdasan Majemuk Siswa Kelas VIII SMP Negeri se-Kota Madiun Tahun Ajaran 2013/2014. Jurnal Elektronik Pembelajaran Matematika, 2(7), 727-739.

Soejono. 1984. Diagnostis Kesulitan Belajar dan Pengajaran Remedial Matematika. Jakarta: P2LPTK.

Sowanto. 2018. Bahan Ajar pada Materi Garis Singgung Lingkaran dengan Pendekatan Saintifik untuk Siswa SMP. KALAMATIKA Jurnal Pendidikan Matematika Volume 3, Nomor 1, April 2018.

Turmudi. 2010. Pembelajaran Matematika: Kini dan Kecenderungan Masa Mendatang. Bandung: FPMIPA UPI.

Yunus, M., Suyitno, H., \& Waluya, S. B. 2013. Pembelajaran TSTS Berbasis Kontruktivisme Berbantuan CD Pembelajaran untuk Menumbuhkan Kemampuan Komunikasi Matematis Siswa. Unnes Journal of Mathematics Education Research, 2(1), 164-169. 